\section{YELLOW-BELLIED SAPSUCKERS}

CAROL C. CLARKE, R.R. No.1, McKague, Saskatchewan. SOE OZO

Our farm is located in east-central Saskatchewan. Several varieties of deciduous trees and spruce remain to provide an excellent habitat for wildlife. With increased utilization of land for agriculture in the surrounding areas, more species migrate to our woodlots. We provide them with protection and aid: winter feed stations, bird houses, water, hunter and cat control. They, in turn, offer us much enjoyment. Among some events, we have rescued a woodchuck from an unused water trough, discovered a beaver on our doorstep and visited a white-tailed doe and her triplets.

Families of Yellow-Bellied Sapsuckers have nested in various locations on the farm. This species of woodpecker drills tiny holes in parallel rows on live trees to make the sap run. They return later to feed upon the sap and the small insects attracted by the sap flow. The first invasion was in the autumn when a single bird started drilling our apple trees. Since the apples are not very hardy, we waxed the holes and covered the trunks to discourage the bird. It was also late in the season so possibly the sap was not running as well as expected or the bird may have migrated south. The damage did however, encourage insect pests the following season.

Last June (1981) a family of sapsuckers nested in a hole in a large live aspen in the barnyard. The parents arrived to attack our silver willows causing extensive damage to the one-inch trunks. Nothing seemed to disrupt their progress and they became very possessive of their trees. This corner happened to be a very busy one with garden cultivating, lawn mowing, greenhouse activities, plus watering the horses daily caused traffic through the hedge. However, undaunted, the birds soon had the sap bubbling and frothing out of the willows.

In the hot days of August the brewery-like stench was nauseous. This seems to delight the fledglings. The family was soon "sipping the brew". Disastrous results of their intoxicated condition were apparent rather quickly. One male fledgling collided with the side of the house breaking' his neck. A second bird was observed flying in a peculiar circular fashion high above the maples. Suddenly, it "nose-dived" straight down into the bushes. We were unable to determine whether it crashlanded or survived the dive. The remaining two (or three) were more bold and less afraid of intruders, people or cats. As silver willows are not very tall shrubs, a constant surveillance of one cat became necessary. I was able to photograph the birds at very close range.

The smell of the fermenting sap attracted other visitors. The most interesting was a family of Ruby-throated Hummingbirds. The sap seemed to affect their usually cautious natures as well as their flight patterns. I was able to approach them very closely. Only one, once it spotted me, became excited and tried to remove the others who largely ignored it. One bird swooped over me while I sat on the lawn and flew almost through my hair. They also squealed more than when they visited the flower beds. The increased vocalization interested the cat, of course.

Insects also indulged in the sap. One group of large flies, which I did not identify, were constantly at the willow's. Hosing them with water removed the flies, but, as the sap flowed rapidly, they returned almost immediately.

I was able to photograph several butterflies that were guests of the sapsuckers. First the White Admirals, who 
normally feed upon aphid honeydew and liquids from carrion and flowers, came in groups. The Red Admirals which usually feed from fruits and flowers were also plentiful. The Gray Comma, who is fond of sap, rotting fruit, carrion and scat as well as a diet of flower nectars, was not observed as commonly as the admirals. There were some Mourning Cloaks and possibly a Large Wood Nymph which is a sap sipper. I was unable to positively identify the nymph.

Hopefully our silver willows have sur- vived the winter regardless of their damaged condition. Although our less hardy shrubs were not invaded there may be more insect pests in the area next season due to the willows. This incident provided us with an interesting encounter with nature, but I would not recommend the procedure as a method of baiting wildife for nature photographers.

PYLE, R. M. 1981. The Audubon Society Field Guide to North American Butterflies. A. A. Knopf, New York. 916 pp.

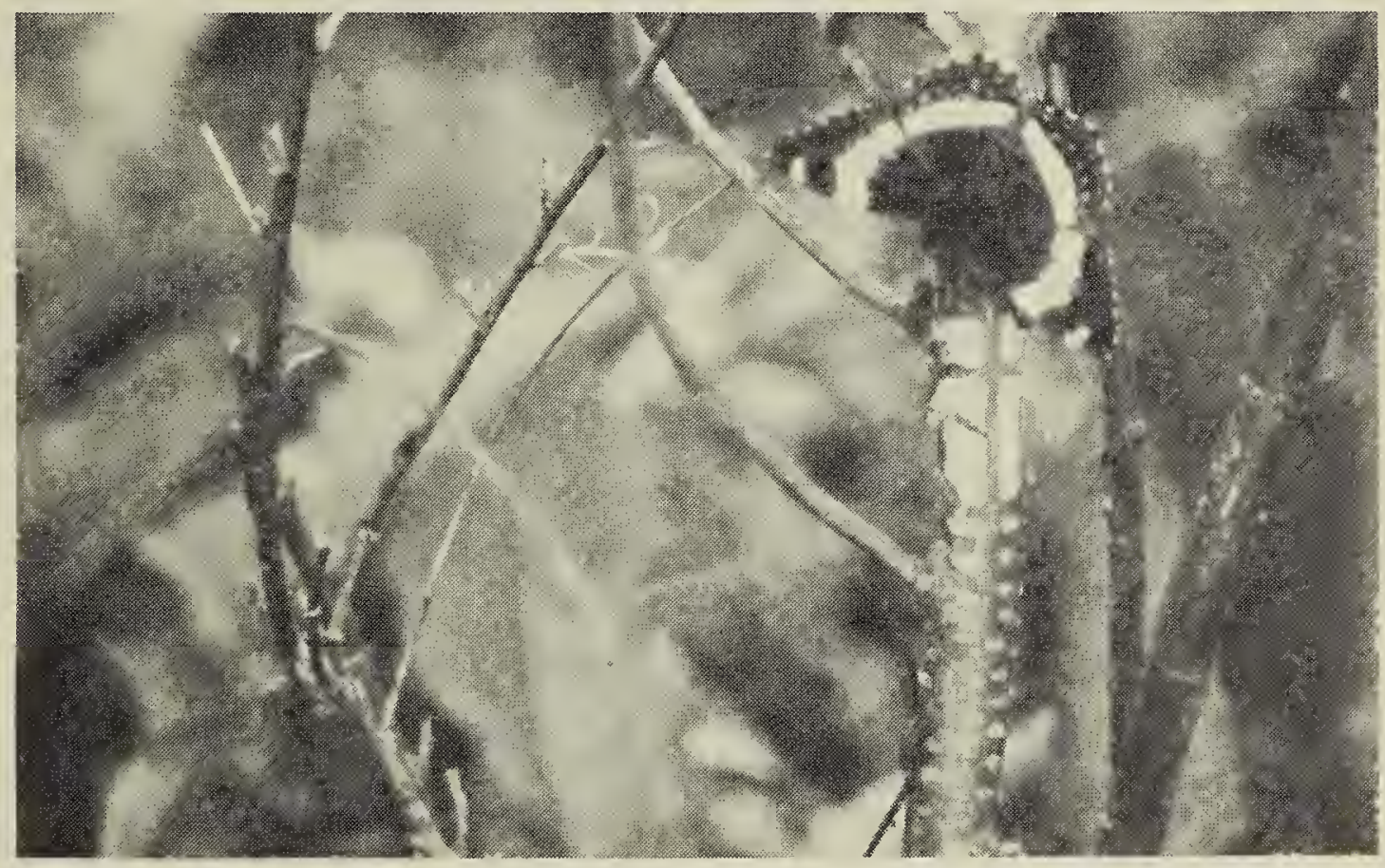

White Adniral at sapsucker drains.

Carol Clarke

\section{BAND-TAILED PIGEON NEAR HERBERT, SASKATCHEWAN}

\section{DONALD A. WEIDL, 2918 Preston} Avenue, Saskatoon, Saskatchewan. S7J $2 \mathrm{G} 9$

On 21 June 1981 three friends and I were visiting relatives north of Herbert. We decided to take a walk to a nearby abandoned schoolyard known as the
Coxley School. As we approached the hedgerow surrounding the school one of my friends spotted a bird that flushed from the Caraganas. It flew across the schoolyard and landed in a tree. My first impression as the bird flew was that it was a Rock Dove, however something didn't appear quite right. I viewed the bird through $7 \times 35$ binoculars at about 100 meters. It was facing me, revealing a large brownish breast and a yellow bill. It was at this time that I suspected I was looking at a Band-tailed Pigeon. Not being familiar with this species I 